\title{
Rice husk filtrate as a nutrient medium for the growth of Desulfotomaculum nigrificans: characterisation and sulfate reduction studies
}

\author{
Evvie Chockalingam ${ }^{\mathrm{a}}$, K. Sivapriya ${ }^{\mathrm{b}}$, S. Subramanian ${ }^{\mathrm{a}, *}$, S. Chandrasekaran ${ }^{\mathrm{b}}$ \\ ${ }^{a}$ Department of Metallurgy, Indian Institute of Science, Bangalore 560 012, India \\ ${ }^{\mathrm{b}}$ Department of Organic Chemistry, Indian Institute of Science, Bangalore 560 012, India
}

\begin{abstract}
The filtrate obtained by interacting a known amount of rice husk with deionised, Milli-Q water was assessed as a carbon source and nutrient medium for the growth of Desulfotomaculum nigrificans, a typical sulfate-reducing bacterium. The filtrate contained essential growth constituents such as magnesium, potassium, phosphorous apart from calcium, sodium, chloride and sulfate ions. Based on the ${ }^{1} \mathrm{H}$ and ${ }^{13} \mathrm{C}$ NMR characterization studies, the organic composition of the components dissolved from the rice husk, was found to be: (i) $66 \%$ lignocellulosic material, (ii) $24 \%$ xylose + arabinose and (iii) $10 \%$ galactose. The growth studies indicated a 15 -fold increase in the bacterial cell number in about 20 days. Nearly $81 \%$ and $66 \%$ reduction in sulfate concentration could be achieved in about 28 days, from the solutions containing initial sulfate concentrations of $550 \mathrm{mg} / \mathrm{l}$ and $1200 \mathrm{mg} / \mathrm{l} \mathrm{respectively}$. In both the cases studied, the iron concentration could be reduced by over $85 \%$.
\end{abstract}

Abbreviations: SRB, sulfate-reducing bacteria; NMR, nuclear magnetic resonance spectroscopy; FTIR, Fourier transform infrared spectroscopy; Dsm., Desufotomacalum

Keywords: Rice husk; Carbon source; SRB; NMR; FTIR; Dsm. nigrificans

\section{Introduction}

In mineral processing operations, large quantities of ore tailings and mine rejects are generated, which are exposed to the vagaries of nature. The metal sulfides present in the tailings are oxidized chemically and biologically to produce large amounts of dissolved metals, sulfate and acidity. The dissolved metals and the sulfuric acid so produced constitute acid mine drainage (AMD). AMD contaminates streams and rivers near mining regions (Hammack et al., 1994; White and Gadd,

\footnotetext{
* Corresponding author. Tel.: +91 802293 2261/2263; fax: +91 80 23600472.

E-mail address: ssmani@metalrg.iisc.ernet.in (S. Subramanian).
}

1996). Conventionally, AMD is neutralized by treatment with lime and $\mathrm{CaCO}_{3}$, but the process is expensive and also results in the generation of large quantities of sludge. Biological sulfate reduction has emerged as an attractive alternative to combat AMD. Under anaerobic conditions, the process can remove metals from solution as metal sulfide precipitates (Dvorak et al., 1992; Hedin et al., 1994). The Pacques technique involves the development of bacterial sulfate reduction, which generates the in situ formation of $\mathrm{H}_{2} \mathrm{~S}$ gas by using simple carbon sources such as ethanol and the precipitation of heavy metal sulfides (Martin, 1991).

The main substrates reported as energy sources for sulfate-reducing bacteria are lactate (Wakao et al., 1979), pyruvate, hydrogen, acetate or fumarate (Fauque 
et al., 1991), ethanol (Kaksonen et al., 2003) and methanol (Vallero et al., 2003).

Some of the naturally occurring complex organic sources have also been considered as energy sources for the growth of sulfate-reducing bacteria and biological sulfate reduction. These include mushroom compost (Hammack and Edenborn, 1992), straw and hay (Béchard et al., 1994), peat sample (Weider et al., 1985; Weider and Lang, 1986), saw dust (Wakao et al., 1979), oak chips (Chang et al., 2000), cow and horse manure (Christensen et al., 1996), and leaves such as pine and eucalyptus (Frank, 2000). Recently, the use of tannery effluent (Boshoff et al., 2004a) and microalgal biomass (Boshoff et al., 2004b), as carbon source for biological sulfate reduction has been reported. However, sulfate-reducing bacteria do not degrade polysaccharides, proteins or lipids but depend on the activity of fermentative bacteria for the supply of energy sources (Hansen, 1988).

In the present investigation, the utility of rice husk filtrate as a carbon source for the growth of Dsm. nigrificans, a typical sulfate-reducing bacterium has been evaluated. A detailed characterization of the rice husk filtrate with respect to its organic and inorganic components has been carried out. The feasibility of sulfate reduction using Dsm. nigrificans in the presence of the rice husk filtrate has also been assessed.

\section{Methods}

\subsection{Substrate}

Rice husk was obtained from a rice mill located in Bangalore, Karnataka, India. The particle size $\left(d_{50}\right)$ of the sample was $0.206 \mathrm{~mm}$ with total carbon: $45.5 \%$, H: $7.3 \%$, N: $1.1 \%$, S: $0.92 \%$ and O: $44.18 \%$. The sample was stored in polythene bottles and used without any other physical or chemical treatment.

\subsection{Bacterial strain}

A pure strain of sulfate-reducing bacterium namely Dsm. nigrificans (NCIM 2834 and NCIB 8788) was obtained from the National Collection of Industrial Microorganisms (NCIM), National Chemical Laboratory (NCL), Pune, India.

\subsection{Reagents}

Sodium sulfate and ferrous ammonium sulfate and all the other salts used in the growth medium were of analytical grade. Deionised water obtained from a Milli-Q system (Millipore, USA) was used for all the experiments. The resistivity of the water was below $20 \mathrm{M} \Omega \mathrm{cm}$.

\subsection{Preparation of the rice husk filtrate}

Exactly $10 \mathrm{~g}$ of the rice husk was interacted with $100 \mathrm{ml}$ of deionised Milli-Q water for $30 \mathrm{~min}$ in an Erlenmeyer flask at $200 \mathrm{rpm}$ in an Orbitek orbital shaker at $30^{\circ} \mathrm{C}$. The suspension was filtered through a Whatman no. 4 filter paper. The filtrate thus obtained was lyophilized using a Virtis Sentri freeze mobile lyophiliser.

\subsection{FTIR spectroscopy studies}

The FTIR spectrum of the lyophilized sample of the rice husk filtrate was recorded using a FTIR spectrometer (JASCO model 410) adopting the $\mathrm{KBr}$ pellet technique in the range of $4000-600 \mathrm{~cm}^{-1}$.

\subsection{Organic elemental analysis}

CHN-O analysis of the lyophilized sample was performed using Thermo Finnigan Flash EA 1112 instrument.

\subsection{Analysis of the inorganic components}

The rice husk filtrate was analysed for all the cations and anions using V G Elemental model PQ3 ICP-MS.

\subsection{Analysis of sugars}

To determine the percentage of the various sugars and lignocellulose material that have been dissolved, about $1 \mathrm{~g}$ of the lyophilized sample was boiled with ethanol for $10 \mathrm{~min}$. The solution was filtered to remove the undissolved materials. The undissolved material was analysed using solid-state ${ }^{13} \mathrm{C}$ NMR (Bruker DSH $300 \mathrm{MHz}$ ). Ethanol was removed from the filtrate using Büchi 461 rotavapour and the crude product was also subjected to spectral analysis like ${ }^{1} \mathrm{H}$ and ${ }^{13} \mathrm{C}$ NMR (JEOL, $300 \mathrm{MHz}$ ). Since xylose and arabinose are isomers, the sugars were separated using 2,4-dinitro phenylhydrazine method, (Vogel, 1989a), by which they are converted into their respective hydrazones and then separated by column chromatography using silica gel (230400 mesh).

\subsection{Preparation of the bacterial cell pellet}

SRB namely Dsm. nigrificans were initially cultured in sealed glass bottles under anaerobic conditions using modified Baars' medium, (Baars, 1930; Grossman and Postgate, 1953; Pankhurst, 1971) as detailed in Table 1. After the complete growth of the bacteria, the culture was first filtered using Whatman 41 filter paper to remove the iron sulfide precipitate. The filtrate containing the bacterial cells was then centrifuged using a Sorvall 
Table 1

Composition of modified Baars' medium

\begin{tabular}{ll}
\hline Components & Amount \\
\hline $\mathrm{K}_{2} \mathrm{HPO}_{4}$ & $0.5 \mathrm{~g} / 1$ \\
$\mathrm{NH}_{4} \mathrm{Cl}$ & $1 \mathrm{~g} / \mathrm{l}$ \\
$\mathrm{CaSO}_{4}$ & $1 \mathrm{~g} / 1$ \\
$\mathrm{MgSO}_{4} \cdot 7 \mathrm{H}_{2} \mathrm{O}$ & $2 \mathrm{~g} / 1$ \\
$\mathrm{Sodium}_{\text {lactate }}$ & $40 \mathrm{ml} / 1$ \\
Yeast extract & $1 \mathrm{~g} / 1$ \\
$\mathrm{FeSO}_{4}\left(\mathrm{NH}_{4}\right)_{2} \mathrm{SO}_{4} \cdot 6 \mathrm{H}_{2} \mathrm{O}$ & $0.5 \mathrm{~g} / 1$ \\
Sodium thioglycollate & $0.02 \mathrm{~g} / 1$ \\
Distilled water & $1000 \mathrm{ml}$ \\
\hline
\end{tabular}

RC-5B refrigerated centrifuge for $20 \mathrm{~min}$ at 15,000 rpm. After centrifugation, the supernatant solution was removed and the cell pellet washed twice with Milli-Q water and centrifuged again. The supernatant was discarded and the bacterial cell pellet thus obtained was used for the growth and sulfate reduction studies in the rice husk filtrate medium. The complete preparation of the cell pellet was carried out under anaerobic conditions.

\subsection{Studies on growth and sulfate reduction using rice husk filtrate}

The rice husk filtrate medium was first sterilized in the presence of sodium sulfate. To this, iron as ferrous ammonium sulfate was added using a membrane filter in separate bottles. The bottles were then inoculated with $\approx 4 \times 10^{7}$ of Dsm. nigrificans cells and closed with tight fitting rubber corks. After inoculation, nitrogen gas was passed through a syringe arrangement into the bottles to maintain anaerobic conditions. The bottles were then maintained at $37 \pm 1{ }^{\circ} \mathrm{C}$ in an Orbitek incubator and the change in iron and sulfate concentrations were monitored periodically. The bacterial cell number was counted simultaneously.

\subsection{Determination of sulfate and iron concentrations}

Sulfate concentration was determined by measuring the turbidity obtained after addition of barium chloride at $420 \mathrm{~nm}$ (APHA, 1989) and iron concentration was determined by the orthophenanthroline method at $512 \mathrm{~nm}$ (Vogel, 1989b), using a Shimadzu UV-260 UV-Visible spectrophotometer.

\subsection{Determination of bacterial cell count}

Bacterial cell number was determined using a PetroffHausser counter attached to a Leitz phase contrast microscope (Laborlux K Wild Mps 12).

\subsection{Electron microscopic studies}

Scanning electron micrograph of Dsm. nigrificans was taken using a JEOL 840A JSM model scanning electron microscope. Prior to observation under the electron microscope, the bacterial sample, which was previously air-dried was made conducting, adopting a gold sputtering technique using a JEOL JFC $1100 \mathrm{E}$ ion sputtering device.

\section{Results and discussion}

The rice husk filtrate after lyophilization was initially characterized with respect to organic and inorganic elemental composition. The FTIR spectrum of the lyophilized sample of the filtrate was recorded. The ethanol soluble and insoluble components of the lyophilized sample were determined. The insoluble components were identified by solid-state ${ }^{13} \mathrm{C}$ NMR and the soluble sugars present in the sample were identified by ${ }^{1} \mathrm{H}$ and ${ }^{13} \mathrm{C}$ NMR spectral investigations. Further characterization of the sugars was done by the ${ }^{1} \mathrm{H}$ NMR studies on the hydrazone derivatives.

\subsection{Organic and inorganic elemental analysis}

The CHN analysis of the lyophilized sample showed the following composition: $\mathrm{C}-36.01 \%$; $\mathrm{H}-6.25 \%$; $\mathrm{N}-1.72 \% ; \mathrm{O}-52.12 \%$.

The various inorganic anions and cations present in the rice husk filtrate are summarised in Table 2. A relatively higher concentration of potassium, magnesium and phosphate ions is found to be present. Other essential elements like calcium, sodium, chloride, sulfate and nitrate are also present in appreciable amounts.

\subsection{FTIR spectroscopy studies}

In order to identify the characteristic functional groups present in the lyophilized rice husk filtrate, the

Table 2

Inorganic elemental analysis of the rice husk filtrate

\begin{tabular}{ll}
\hline Elements & Concentration $(\mathrm{mg} / \mathrm{l})$ \\
\hline Potassium & 481 \\
Magnesium & 101 \\
Sodium & 25 \\
Calcium & 11.6 \\
Manganese & 0.74 \\
Iron & 0.32 \\
Boron & 0.19 \\
Copper & 0.15 \\
Zinc & 0.14 \\
Phosphate & 217 \\
Chloride & 55 \\
Sulfate & 24.40 \\
Nitrate & 20.15 \\
\hline
\end{tabular}


FTIR spectrum was recorded (Fig. 1). A broad band centered at $3428 \mathrm{~cm}^{-1}$ indicates the presence of $-\mathrm{OH}$ groups. This stretching is due to both the silanol groups ( $\mathrm{Si}-\mathrm{OH})$ and adsorbed water on the rice husk surface as also reported by Kamath and Proctor (1998). The small peak at $2926 \mathrm{~cm}^{-1}$ may be attributed to the stretching of $-\mathrm{OH}$ groups bound to methyl radicals. These groups are present in the lignin structure and the peak at $1653 \mathrm{~cm}^{-1}$ is characteristic of carbonyl stretching from aldehydes and ketones (Tarley and Arruda, 2004; López and Herrera, 1997). The peaks at 1450 and $1417 \mathrm{~cm}^{-1}$ are due to the stretching in aromatic rings, while deformations related to $\mathrm{C}-\mathrm{H}$ and $\mathrm{C}-\mathrm{O}$ bonds are observed in the region $1153-1023 \mathrm{~cm}^{-1}$.

\subsection{NMR studies on alcohol insoluble component}

The solid-state ${ }^{13} \mathrm{C}$ NMR spectrum of the alcoholinsoluble residue of the lyophilized sample is shown in Fig. 2. The spectrum shows the presence of lignin-cellulose structure. The signal identity is associated with the resonance lines of glucose, which is the repeating unit in cellulose, and display different signals as follows: $\mathrm{C}-1$ at 102 ppm, C-2 and C-3 at 72 and 81 ppm, C-5 at 99 ppm, $\mathrm{C}-4$ and C-6 at $93 \mathrm{ppm}$ and $63 \mathrm{ppm}$ respectively. A broad signal at $174 \mathrm{ppm}$ represents the carboxyl carbon. A range of peaks from 120 to $150 \mathrm{ppm}$ can be attributed to the aromatic carbon. This is in good agreement with the results reported by Tarley and Arruda (2004).

\subsection{NMR studies on soluble sugars}

In order to determine the soluble sugar compounds, the lyophilized powder was boiled with ethanol and the mixture was filtered. The dissolved material was found to be a mixture of sugars namely xylose, arabi- nose and galactose and was confirmed by spotting the authentic samples of the respective sugars using TLC. The NMR studies of the dissolved material revealed the following characteristics:

From the ${ }^{1} \mathrm{H}$ NMR $\left(\mathrm{D}_{2} \mathrm{O}\right)$ spectrum (Fig. 3), it is noteworthy that the above-mentioned sugars have the characteristic anomeric proton (C-1), which appears as a doublet at $5.22 \mathrm{ppm}$. The characteristic ring protons C-2, C-3, C-4 and C-5 appear as a broad peak between 3.01 and $3.89 \mathrm{ppm}$.

The ${ }^{13} \mathrm{C}\left(\mathrm{D}_{2} \mathrm{O}\right)$ peaks are very sharp and clear and the absence of the peaks between 120 and $150 \mathrm{ppm}$ indicates the absence of lignin and the cellulosic material in this alcohol dissolved material. The characteristic resonance peaks for xylose, arabinose and galactose are marked in Fig. 4. The C-1 peak is at $104 \mathrm{ppm}$. Since arabinose and xylose are isomers their ${ }^{13} \mathrm{C}$ peaks are merged and appear as a single peak for C-2, C-3, C-4, C-5 [69-92 ppm]. The $\mathrm{C}-6$ carbon of galactose appears at $63 \mathrm{ppm}$. The peak at $215 \mathrm{ppm}$ indicates the presence of $\mathrm{CHO}$ group, which attests to the open chain structure of the sugars.

\subsection{Characterisation of the hydrazone derivatives of the soluble sugars}

Galactose derivative: The ${ }^{1} \mathrm{H}$ NMR shows a broad peak at $7.6 \mathrm{ppm}$ (aromatic protons). C-1: $5.3 \mathrm{ppm}, \mathrm{C}$ 5: $4.04 \mathrm{ppm}, \mathrm{C}-2, \mathrm{C}-3, \mathrm{C}-4$ and C-6 appear between 3.55 and 3.81 ppm (Fig. 5).

Mixture of xylose and arabinose derivative: Since xylose and arabinose are isomers, only the mixture of the hydrazone derivative could be obtained. The aromatic protons appear between 7.79 and $9.13 \mathrm{ppm}$ while the $-\mathrm{NH}$ proton of the hydrazone appears at $8.38 \mathrm{ppm}$. The sugar protons appear in the range between 3.71 and 5.41 ppm (Fig. 6).

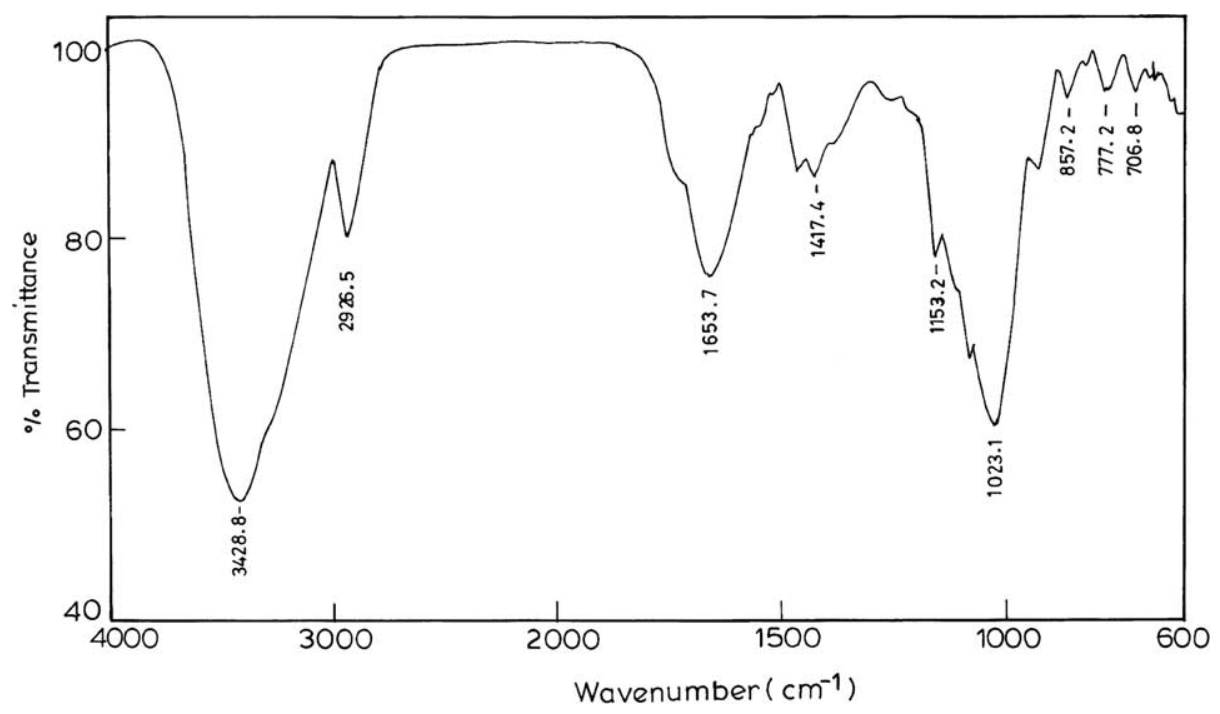

Fig. 1. FTIR spectrum of lyophilized rice husk filtrate. 


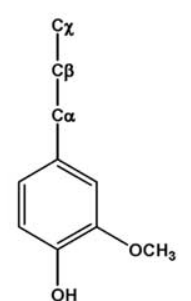

Lignin

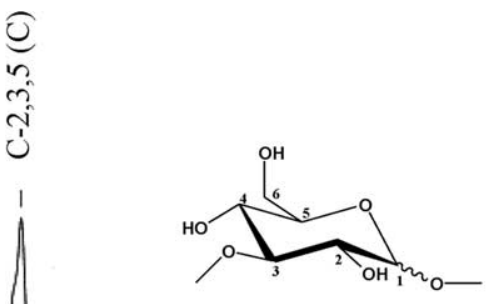

Cellulose

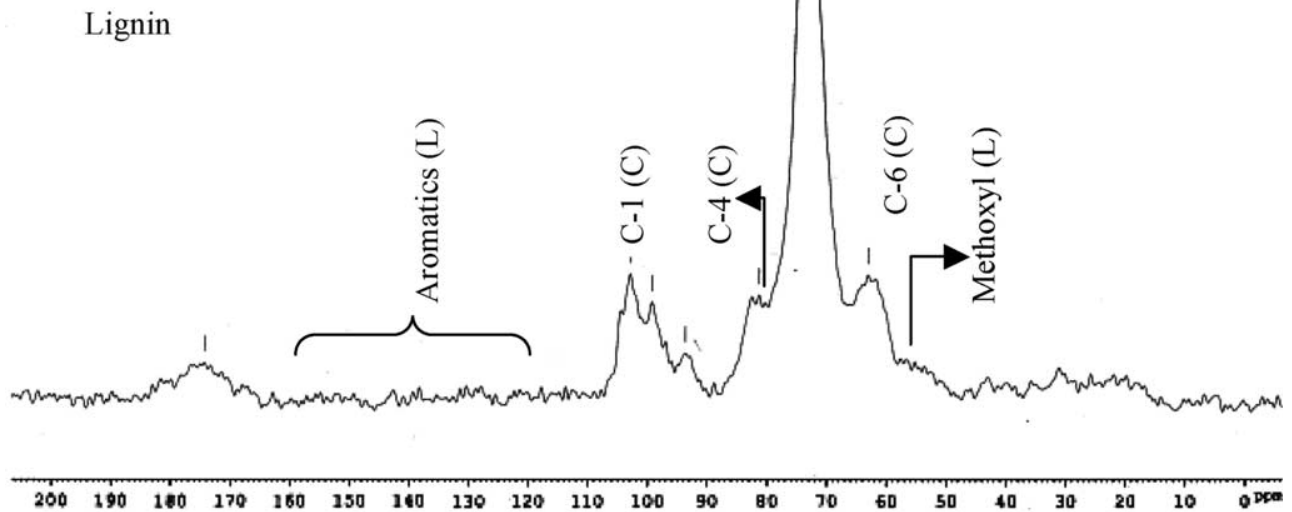

Fig. 2. ${ }^{13} \mathrm{C}$ NMR spectrum of the alcohol-insoluble residue showing the presence of lignin and cellulose component (C-cellulose; L-lignin).

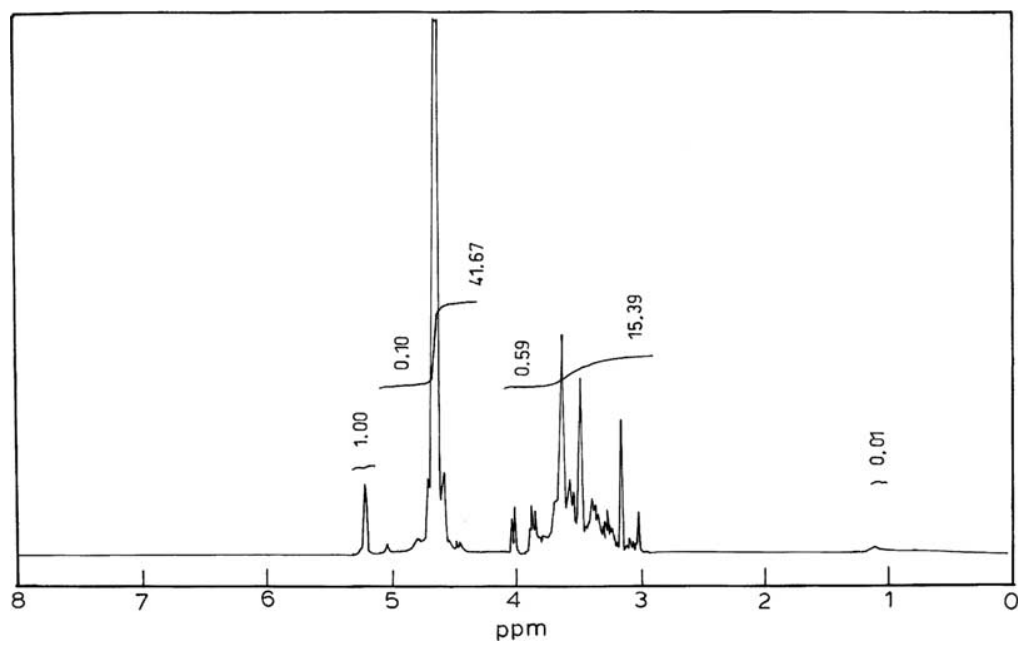

Fig. 3. ${ }^{1} \mathrm{H}$ NMR spectrum of the mixture of sugars (arabinose, xylose and galactose).

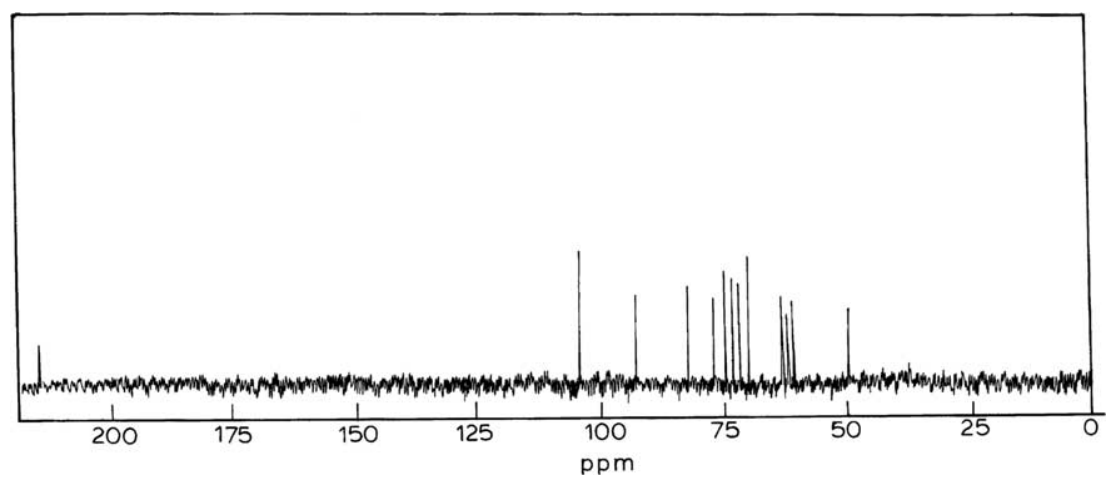

Fig. $4 .{ }^{13} \mathrm{C}$ NMR spectrum of the mixture of sugars (arabinose, xylose and galactose). 


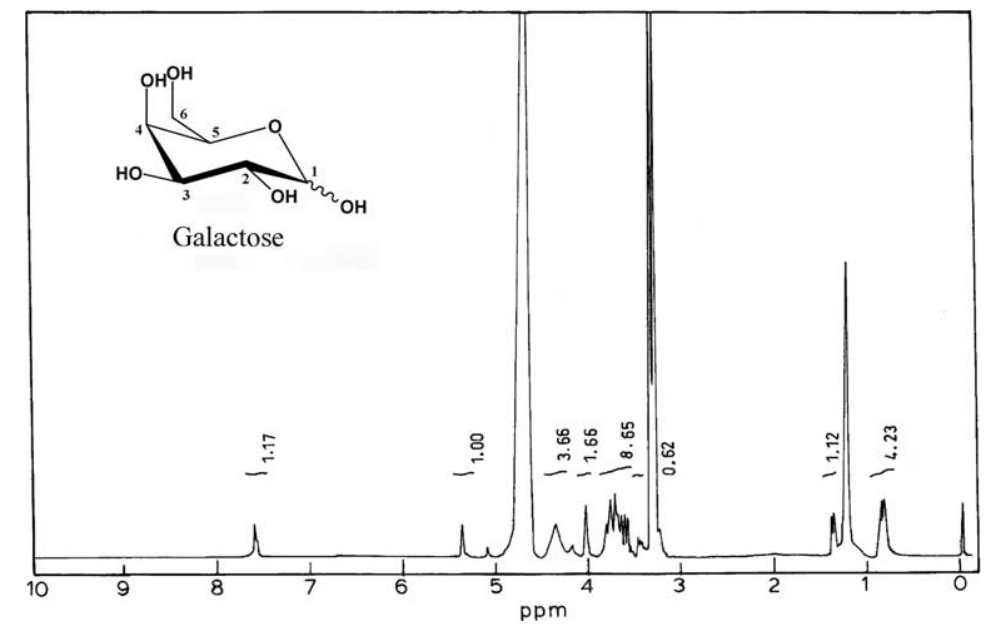

Fig. 5. ${ }^{1} \mathrm{H}$ NMR spectrum of the hydrazone derivative of galactose.

Based on the characterization studies, the organic composition of the components dissolved from the rice husk, is found to be:

Lignocellulosic material: $66 \%$.

Xylose + arabinose mixture: $24 \%$.

Galactose: $10 \%$.

These findings are in good agreement with the results of Karera et al. (1986). It thus becomes of interest to explore the utility of the rice husk filtrate as a growth medium for Dsm. nigrificans and concomitant sulfate reduction.

\subsection{Growth of Dsm. nigrificans and sulfate reduction studies using rice husk filtrate}

The feasibility of growth of Dsm. nigrificans and sulfate reduction using rice husk filtrate was assessed under the following conditions: (a) $550 \mathrm{mg} / \mathrm{l}$ of sulfate and $50 \mathrm{mg} / \mathrm{l}$ of iron.

(b) $1200 \mathrm{mg} / \mathrm{l}$ of sulfate and $75 \mathrm{mg} / \mathrm{l}$ of iron.

Fig. 7 shows the increase in cell number as a function of time for both the conditions studied. The cell number steeply increases up to about 20 days and thereafter attains a saturation value of about $7 \times 10^{8}$ cells $/ \mathrm{ml}$ using rice husk filtrate, though it takes only 8 days to attain the full growth of $4 \times 10^{8}$ cells $/ \mathrm{ml}$ with the modified Baars' medium. On a comparative basis, the cell growth is marginally higher with increased iron and sulfate concentrations. It is worthy of mention that the growth of Dsm. nigrificans cells in the rice husk filtrate medium is found to be comparable or even better than that of the cells grown in the modified Baars' medium. It was also observed that there was an initial decrease in the $\mathrm{pH}$ value in both the cases during the growth of the bacteria. This could be attributed to the degradation of the sugars to fatty acids as reported by Chang et al. (2000).

The variation in the sulfate concentration as a function of time for the two conditions studied is portrayed

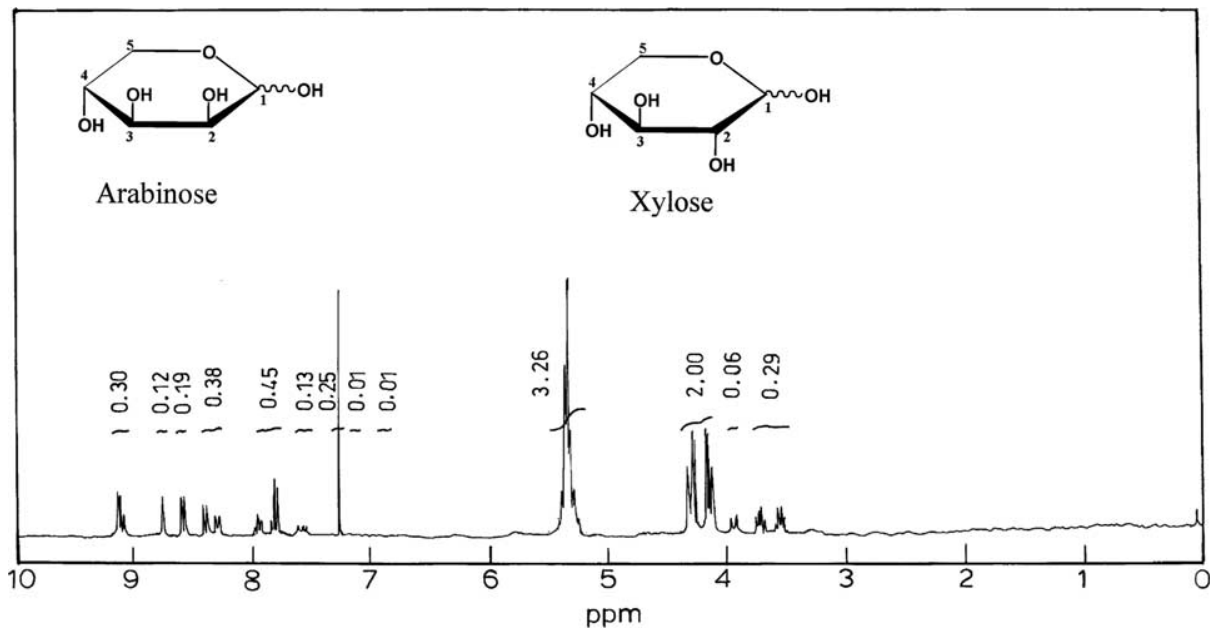

Fig. 6. ${ }^{1} \mathrm{H}$ NMR spectrum of the hydrazone derivative of arabinose and xylose. 


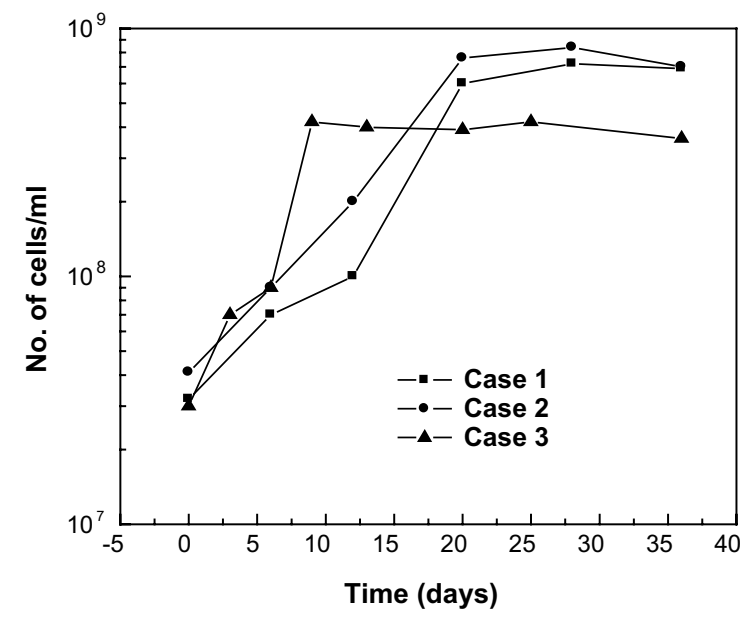

Fig. 7. Growth curve of Dsm. nigrificans as a function of time. Case 1: $550 \mathrm{mg} / \mathrm{l}$ sulfate $+50 \mathrm{mg} / \mathrm{l}$ iron; Case $2: 1200 \mathrm{mg} / \mathrm{l}$ sulfate $+75 \mathrm{mg} / \mathrm{l}$ iron; Case 3: modified Baars' medium.

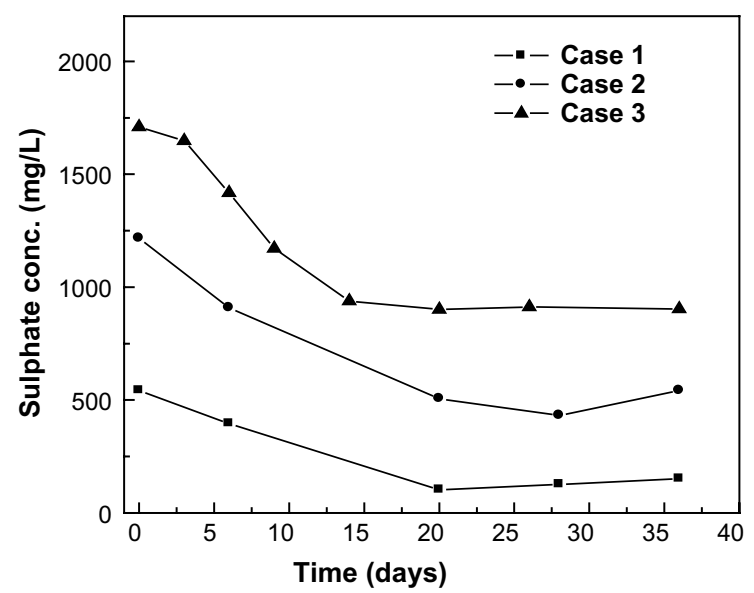

Fig. 8. Variation in sulfate concentration as a function of time. Case 1: $550 \mathrm{mg} / \mathrm{l}$ sulfate $+50 \mathrm{mg} / \mathrm{l}$ iron; Case $2: 1200 \mathrm{mg} / 1$ sulfate $+75 \mathrm{mg} / 1$ iron; Case 3: modified Baars' medium.

in Fig. 8. The sulfate concentration decreases from $550 \mathrm{mg} / \mathrm{l}$ to about $100 \mathrm{mg} / \mathrm{l}$ in 20 days and more or less remains at that concentration thereafter. In the case of the experiment carried out with an initial sulfate concentration of $1200 \mathrm{mg} / \mathrm{l}$, a steady decrease in sulfate concentration is observed and after 28 days, the concentration is reduced to $430 \mathrm{mg} / \mathrm{l}$. Subsequently, the sulfate concentration is found to marginally increase to about $520 \mathrm{mg} / \mathrm{l}$ in 36 days. This can be attributed to the depletion of the easily degradable organic material in the medium as reported by other workers (Christensen et al., 1996; Chang et al., 2000; Frank, 2000). The sulfate concentration being several orders of magnitude higher as compared to the metal ion concentration could only be removed by reduction to $\mathrm{H}_{2} \mathrm{~S}$ and thus complete removal is not feasible. Further, carbon is the limiting reactant in the SRB metabolism. About $81 \%$ and $64 \%$ reduction in sulfate concentration could be achieved for case (a) and

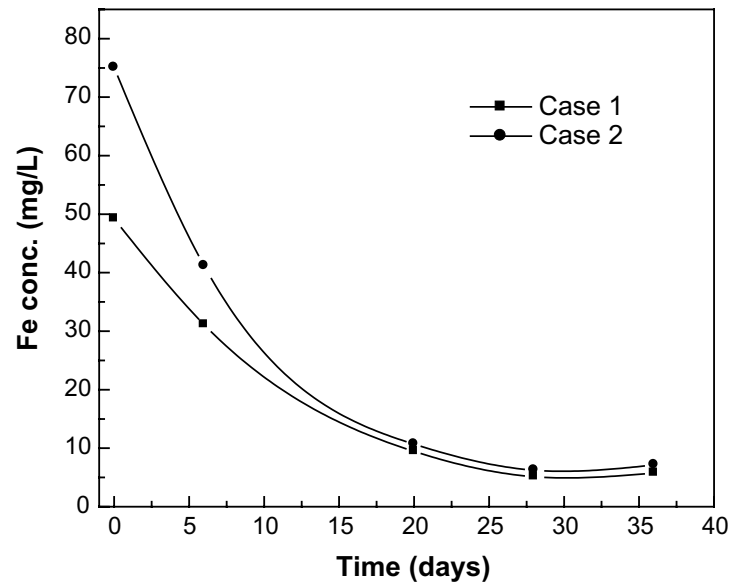

Fig. 9. Variation in iron concentration as a function of time. Case 1: $550 \mathrm{mg} / \mathrm{l}$ sulfate $+50 \mathrm{mg} / \mathrm{l}$ iron; Case $2: 1200 \mathrm{mg} / \mathrm{l}$ sulfate $+75 \mathrm{mg} / \mathrm{l}$ iron.

case (b) respectively after 28 days. On a comparative basis, the sulfate reduction kinetics is slower, with increase in sulfate concentration from 550 to $1200 \mathrm{mg} / \mathrm{l}$.

Simultaneously, the change in the iron concentration was monitored as a function of time and the results are depicted in Fig. 9. The iron concentration steadily decreases with time and attains a value of about $10 \mathrm{mg} / \mathrm{l}$ after 20 days in both cases, though the initial concentrations were different. There is not much of a difference in the kinetics of iron reduction beyond 20 days. The final iron concentration is about $5-7 \mathrm{mg} / \mathrm{l}$ after 36 days. The percentage of iron reduction is about $86 \%$ for the cases (a) and (b) studied.

A typical scanning electron micrograph of Dsm. nigrificans grown in rice husk filtrate medium is shown in Fig. 10. The characteristic rod shaped morphology of the microorganism is distinctly apparent. At a few places, small agglomerated particles of lignocellulosic

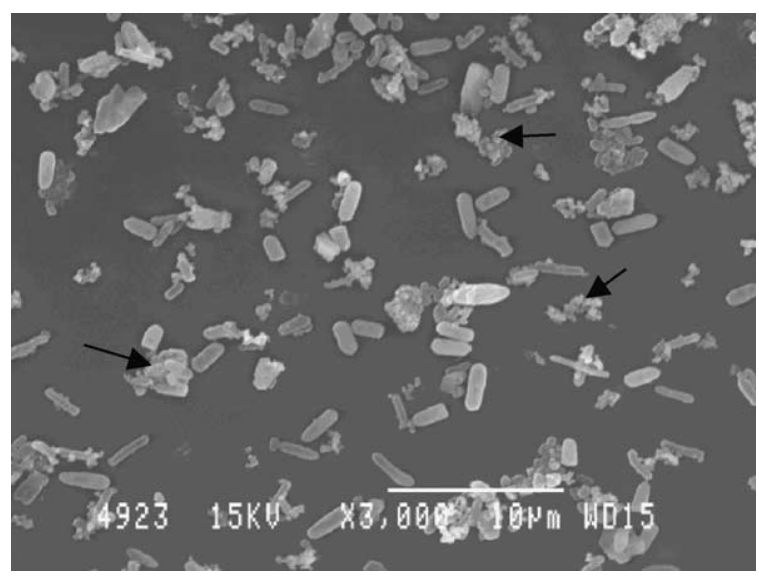

Fig. 10. Scanning electron micrograph of Dsm. nigrificans grown in rice husk filtrate medium (arrows indicate small agglomerated particles of lignocellulosic material). 
material can be observed (as indicated by arrows). It has been reported that lignocellulosic materials are not used up by the sulfidogens (Chang et al., 2000).

The mechanism of sulfate reduction in the presence of organic carbon could be illustrated as:

$2 \mathrm{CH}_{2} \mathrm{O}+\mathrm{SO}_{4}^{2-}+\mathrm{H}^{+} \rightarrow 2 \mathrm{CO}_{2}+2 \mathrm{H}_{2} \mathrm{O}+\mathrm{HS}^{-}$

$\mathrm{M}^{2+}+\mathrm{HS}^{-} \rightarrow \mathrm{MS}+\mathrm{H}^{+}$

where $\mathrm{CH}_{2} \mathrm{O}$ are the sugars and $\mathrm{M}$ represents the metal ion.

It is well documented that the sugars are degraded to fatty acids and alcohols, that facilitate the growth of the bacteria (Chang et al., 2000).

\section{Conclusions}

From the results of the present investigation, the following conclusions can be arrived at:

1. A detailed analysis of the inorganic composition of the rice husk filtrate indicates the presence of magnesium, potassium, phosphorous, calcium, sodium, sulfate, chloride and nitrate ions, which are vital ingredients for the growth of Dsm. nigrificans.

2. The lyophilized filtrate has a carbon content of $36 \%$, which is the main energy source for the growth of sulfate-reducing bacteria.

3. Solid state ${ }^{13} \mathrm{C}$ NMR studies of the alcohol insoluble residue of the lyophilized filtrate shows the presence of lignocellulosic material.

4. ${ }^{1} \mathrm{H}$ and ${ }^{13} \mathrm{C}$ NMR studies have confirmed the presence of soluble sugars, namely xylose, arabinose and galactose in the lyophilized filtrate.

5. Based on the NMR spectral studies, the organic composition of the rice husk filtrate is arrived at to be: lignocellulose $-66 \%$, xylose + arabinose $-24 \%$ and galactose- $-10 \%$.

6. The rice husk filtrate was found to be a good substrate for the growth of Dsm. nigrificans cells.

7. About $81 \%$ and $64 \%$ reduction in sulfate concentration could be achieved in about 28 days, from the solutions containing initial sulfate concentration of $550 \mathrm{mg} / \mathrm{l}$ and $1200 \mathrm{mg} / \mathrm{l}$ respectively.

8. The iron concentration could be reduced by over $85 \%$ from an initial concentration of 50 and $75 \mathrm{mg} / \mathrm{l}$.

\section{Acknowledgement}

The authors are grateful to the Indo-French Centre for Promotion of Advanced Research (CEFIPRA) and the Institute for Research and Development (IRD) France, for grant of research projects to carry out this investigation. The authors thank the help and support given by Ms. K. Eaazhisai (Department of Molecular Biophysics) in using the lyophilization unit.

\section{References}

APHA, 1989. Standard Methods for the Examination of Water and Wastewater, 17th ed. American Public Health Association, Washington, DC.

Baars, J.K., 1930. Over Sulfate Reductive Door Bacterin. Dissertation, University of Delft, Holland.

Béchard, G., Yamazaki, H., Gould, W.D., Bédard, P., 1994. Use of cellulosic substrates for the microbial treatment of acid mine drainage. J. Environ. Qual. 23, 111-116.

Boshoff, G., Duncan, J., Rose, P.D., 2004a. Tannery effluent as a carbon source for biological sulfate reduction. Water Res. 38, 2651-2658.

Boshoff, G., Duncan, J., Rose, P.D., 2004b. The use of micro-algal biomass as a carbon source for biological sulfate-reducing systems. Water Res. 38, 2659-2666.

Chang, I.S., Shin, P.K., Kim, B.J., 2000. Biological treatment of acid mine drainage under sulfate-reducing conditions with solid waste materials as substrate. Water Res. 34, 1269-1277.

Christensen, B., Laake, M., Lien, T., 1996. Treatment of acid mine water by sulfate-reducing bacteria: results from a bench scale experiment. Water Res. 30, 1617-1624.

Dvorak, D.H., Hedin, R.S., Edenborn, H.M., McIntire, P.E., 1992. Treatment of metal contaminated water using bacterial sulfate reduction: results from a pilot-scale reactor. Biotechnol. Bioeng. 40, 609-616.

Fauque, G., LeGall, J., Barton, L.L., 1991. Sulfate-reducing and sulfur-reducing bacteria. In: Shively, J.M., Barton, L.L. (Eds.), Variations in Autotrophic Life. Academic Press Limited, London, pp. 271-337, Chapter 10.

Frank, P., Bioremediation by sulfate-reducing bacteria of acid mine drainage. Available from: <http://ist-socrates.berkely.edu/ es196/ projects/2000final/frank.pdf $>$

Grossman, J.P., Postgate, J.R., 1953. Cultivation of sulfate reducing bacteria. Nature 171, 600-602.

Hammack, R.N., Edenborn, H.M., 1992. The removal of Nickel from mine water using bacterial sulfate reduction. Appl. Microbiol. Biotechnol. 37, 674-678.

Hammack, R.W., Edenborn, H.M., Dvorak, D.H., 1994. Treatment of water from an open-pit copper mine using biogenic and limestone: a feasibility study. Water Res. 28, 2321-2329.

Hansen, T.A., 1988. Physiology of sulfate-reducing bacteria. Microbiol Sci. $5,81-84$.

Hedin, R.S., Narin, R.W., Kleinmann, R.P., 1994. Passive treatment of coal mine drainage. US Bureau of Mines IC9389, 2-35.

Kaksonen, A.H., Franzmann, P.D., Puhakka, J.A., 2003. Performance and ethanol oxidation kinetics of a sulfate-reducing fluidized-bed reactor treating acidic metal-containing wastewater. Biodegradation 14, 207-217.

Kamath, S.R., Proctor, A., 1998. Silica gel from rice hull ash. Cereal Chem. 75, 484- 487.

Karera, A., Nargis, S., Patel, S., Patel, M., 1986. Silicon-based materials from rice husk. J. Sci. Ind. Res. 45, 441-448.

López Pasquali, C.E., Herrera, H., 1997. Pyrolysis of lignin and IR analysis of residues. Thermochim. Acta 293, 39-46.

Martin, D., 1991. Perspectives in water biotreatment. Chem. Britain 2, 882-884.

Pankhurst, E.S., 1971. The isolation and enumeration of sulphatereducing bacteria. In: Shapton, D.A., Board, R.G. (Eds.), Isolation of Anaerobes. Academic Press, London, pp. 223-240. 
Tarley, C.R.T., Arruda, M.A.Z., 2004. Biosorption of heavy metals using rice milling by-products. Characterization and application for the removal of metals from aqueous effluents. Chemosphere 54, 987-995.

Vallero, M.V.G., Hulshoff Pol, L.W., Letting, G., Lens, P.N.L., 2003. Effect of $\mathrm{NaCl}$ on thermophilic $\left(55^{\circ} \mathrm{C}\right)$ methanol degradation in sulfate-reducing granular sludge reactors. Water Res. 37, 2269-2280.

Vogel, A.I., 1989a. Vogels's Text Book of Practical Organic Chemistry, fifth ed. Longman, London.

Vogel, A.I., 1989b. Vogel's Textbook for Quantitative Chemical Analysis, fifth ed. Longman, London.

Wakao, N., Takahashi, T., Sakurai, Y., Shiota, H., 1979. A treatment of acid mine water using sulfate-reducing bacteria. J. Ferment. Technol. 57, 445-452.
Weider, R.K., Lang, G.E., Whitehouse, A.E., 1985. Metal removal in Sphagnum dominated wetlands: experience with a man-made wetland system. In: Brooks, R.P., et al. (Eds.), Wetlands and Water Management on Mined Lands. Pennsylvania State University Park, PA, pp. 353-364.

Weider, R.K., Lang, G.E., 1986. Fe, Al, Mn and S chemistry of Sphagnum peat in four peatlands with different metal and sulphur input. Water Air Soil Pollut. 29, 309-320.

White, C., Gadd, G.M., 1996. Mixed sulfate-reducing bacterial cultures for bioprecipitation of toxic metals: factorial and response-surface analysis of the effects of dilution rate, sulfate and substrate concentration. Microbiology 142, 21972205 . 